\title{
Prevalence of Beta Lactamases Genes in Sewage and Sludge Treated in Mechanical-Biological Wastewater Treatment Plants
}

\author{
Wiktor Zieliński1*, Martyna Buta', Jakub Hubeny', Ewa Korzeniewska1, \\ Monika Harnisz', Monika Nowrotek², Grażyna Płaza² \\ 1 Department of Environmental Microbiology, Faculty of Environmental Sciences, University of Warmia and \\ Mazury in Olsztyn, Poland \\ 2 Department of Environmental Microbiology, Institute for Ecology of Industrial Areas, Katowice, Poland \\ * Corresponding author's e-mail: wiktor.zielinski@uwm.edu.pl
}

\begin{abstract}
Wastewater treatment plants (WWTPs) are a very important link in the spread of antibiotic resistance genes to the environment and the formation of antibiotic-resistant microorganisms. The mechanical and biological methods of wastewater treatment in WWTPs do not completely remove the resistance genes from sewage. The genes responsible for extended-spectrum beta-lactamases (ESBLs) are very common in the family Enterobacteriaceae that colonize the human digestive tract and are abundant in wastewater. The aim of this study was to analyze the prevalence of genes encoding beta-lactamases in the wastewater and sludge samples collected from two WWTPs in the Polish regions of Warmia and Silesia and from the river water upstream and downstream from the WWTPs. The wastewater samples were passed through polycarbonate membrane filters, whereas the sludge samples were homogenized, and genomic DNA was extracted. The $b l a_{\mathrm{TEM}}, b l a_{\mathrm{OXA}}$ and $b l a_{\mathrm{SHV}}$ genes were detected by means of standard PCR. The most prevalent gene was bla $_{\text {TEM }}$ which occurred in all samples, including the treated wastewater. The $b l a_{\mathrm{OXA}}$ gene was also frequently detected in all samples from the WWTP in Silesia. The $b l a_{\mathrm{SHV}}$ gene was least prevalent in the tested samples. These results indicate that wastewater is a hotspot for resistant bacteria. Beta-lactamase genes are not eliminated through the mechanical-biological wastewater treatment methods, and they can spread to other environments, thus increasing the pool of antibiotic resistance genes around the world and creating epidemiological risks.
\end{abstract}

Keywords: WWTPs, beta-lactamases, wastewater treatment, antibiotic resistance genes

\section{INTRODUCTION}

The increased use of antibiotics in human medicine, veterinary medicine and agriculture contributes to the growth of antibiotic resistance among pathogenic bacteria, and it increases the prevalence of multidrug-resistant pathogens in the human environment [Reinthaler et al. 2010; Korzeniewska and Harnisz 2013a; Xu et al. 2015]. Numerous analyses of hospital wastewater have revealed the presence of antibiotic-resistant bacteria (ARB) and antibiotic resistance genes (ARGs). The occurrence of ARGs and ARB in municipal wastewater and their transmission to the environment from wastewater treatment plants give a serious cause for concern [Huang et al. 2012; Chagas et al. 2010].
Wastewater treatment plants play a very important role in the emergence and spread of ARB and ARGs to the environment, in particular water bodies [Rizzo et al. 2013; Osińska et al. 2017]. Wastewater of diversified origin is pooled and mixed in WWTPs [Amador et al. 2014]. The conventional biological methods of wastewater treatment do not completely eliminate the antibiotic resistance genes due to high microbial density and the abundance of the nutrients required for bacterial growth [Kelly et al. 2009]. The research into the effects of different wastewater treatment methods on the occurrence of resistance determinants in the wastewater microbiome demonstrated that the antibiotic-resistant bacteria are more prevalent in effluents than in the incoming sewage [West et. al 2010; Korzeniewska et al. 2013]. 
High concentrations of ARGs and ARB in the wastewater treated in WWTPs give cause for concern because ARGs can spread through horizontal gene transfer (HGT) [Moura et al. 2012; Marti et al. 2014; Korzeniewska and Harnisz 2018].

Beta-lactamases are bacterial enzymes that confer resistance to beta-lactams in microorganisms. The beta-lactamase-producing bacteria were found in many wastewater and water samples. These bacterial enzymes hydrolyze several classes of antibiotics, including cephalosporins, carbapenems and penicillin. A new group of enzymes, extended-spectrum beta-lactamases (ESBLs), was discovered in the mid-1980s. Under typical circumstances, ESBLs are derived from beta-lactamase genes by mutation. Broad-spectrum beta-lactam antibiotics are susceptible to hydrolysis by ESBLs. The prevalence of ESBLproducing bacteria has been gradually increasing. More than 300 ESBL gene variants have been identified to date [Korzeniewska and Harnisz 2013; Reinthaler et al. 2010]. They were categorized into groups A and D of the Ambler scheme and classified into several ESBL gene families [Paterson and Bonomo 2005]. The most prevalent classes include TEM, SHV and CTX-M. The extended-spectrum beta-lactamase resistance genes are genetically diverse and exceedingly mobile. Their mobility can be attributed to the most widespread mobile genetic elements such as plasmids, transposons and integrons. Horizontal gene transfer plays an important role in the spread of resistance to different strains, species and even reservoirs. Among the used groups of antibiotics, beta-lactams are the most widely prescribed antibiotics around the world [Diallo et al. 2014; ECDC 2017]. The growing prevalence of the beta-lactamase transmitting bacteria is a major clinical problem around the world which increases the incidence of infections and reduces the therapeutic efficacy [Li et al. 2009].

The objective of this study was to investigate the prevalence of the genetic determinants of beta-lactamases in the wastewater at each stage of mechanical and biological treatment in WWTPs. The $b l a_{\mathrm{TEM}}, b l a_{\mathrm{SHV}}$ and $b l a_{\mathrm{OXA}}$ genes were analyzed by means of standard polymerase chain reaction (PCR). The study provides valuable new data on the occurrence of the most popular genes responsible for the proliferation of beta-lactamase-producing bacteria. The effectiveness of wastewater treatment processes in each stage of treatment, including in the treated and evacuated effluents, was also analyzed.

\section{MATERIALS AND METHODS}

\section{Characteristics of WWTPs and sampling}

The samples of sewage, water and sludge were collected from two wastewater treatment plants in Poland. Both plants are characterized by a highly similar structure and methods of purification, but one of WWTPs is located in a forested area in the Warmia and Mazury regions (nonindustrialized area), whereas the other WWTP is situated in an industrial area in the Region of Silesia. The treated effluents are discharged into the Lyna River and the Gostynia River, respectively [Korzeniewska and Harnisz 2013; Harnisz and Korzeniewska 2018]. Additional information about both WWTPs can be found in Table 1 .

The samples were collected twice in June and November 2018. The following samples were collected from the WWTP in Warmia and Mazury: river water upstream from the WWTP, raw wastewater, wastewater after passage through the preliminary settling tank, wastewater after passage through the biological chamber, wastewater after passage through the reactor, treated wastewater, river water downstream from the WWTP, sludge after passage through the fermentation pool, and deposited sludge. In turn, the following samples were collected from the WWTP in Silesia: river water upstream from the WWTP, raw wastewater, wastewater after passage through the initial settling tank, wastewater after passage through the secondary settling tank, wastewater after passage through the selector and the C-TECH reactor, treated wastewater, river water downstream from the WWTP, leachate after drainage, sludge after mechanical thickening, and sludge after gravity thickening. The wastewater samples were collected into sterile bottles, and the sludge samples were collected into sterile specimen jars. The material was transported to the laboratory on the same day and stored in a refrigerator for further analysis.

\section{Isolation of genomic DNA}

In order to prepare the samples for the extraction of genomic DNA, the sewage and water samples were filtered using a vacuum pump with $0.20 \mu \mathrm{m}$ filters. The amount of filtrated samples is given in Table 2. Genomic DNA was isolated from the sewage and water samples with the DNeasy Power Water Kit (Qiagen), and from 
Table 1. Technical information about the sewage treatment plants

\begin{tabular}{|c|l|l|l|c|}
\hline $\begin{array}{c}\text { Wastewater } \\
\text { treatment } \\
\text { plant }\end{array}$ & \multicolumn{1}{|c|}{$\begin{array}{c}\text { Type of } \\
\text { the wastewater treatment } \\
\text { technologies modifications }\end{array}$} & \multicolumn{1}{c|}{$\begin{array}{c}\text { Biological section of } \\
\text { wastewater treatment process }\end{array}$} & $\begin{array}{c}\text { Type of } \\
\text { Inflowing wastewater }\end{array}$ & $\begin{array}{c}\text { Average } \\
\text { process } \\
\text { capacity } \\
\left(\mathrm{m}^{3} / \mathrm{d}\right)\end{array}$ \\
\hline $\begin{array}{c}\text { Warmia and } \\
\text { Mazury region }\end{array}$ & $\begin{array}{l}\text { Mechanical-biological } \\
\text { system with elevated } \\
\text { removal of nutrients } \\
\text { (MB-ERN) }\end{array}$ & $\begin{array}{l}\text { Pre-denitrification chamber, phosphorus } \\
\text { removal tank, nitrification/denitrification } \\
\text { chambers, secondary settling tanks }\end{array}$ & $\begin{array}{l}\text { Domestic sewage + } \\
\text { hospital sewage + } \\
\text { wastewater from } \\
\text { food industry }\end{array}$ & 35000 \\
\hline $\begin{array}{c}\text { Silesian } \\
\text { region }\end{array}$ & $\begin{array}{l}\text { Mechanical-biological } \\
\text { processes and chemical } \\
\text { processes in the form of } \\
\text { phosphorus precipitation }\end{array}$ & $\begin{array}{l}\text { Sequential reactors (C-TECH) and activated } \\
\text { sludge chambers (the system of chambers } \\
\text { of different oxygen conditions: anaerobic, } \\
\text { anoxic and aerobic), secondary settling } \\
\text { tank, anoxic chamber }\end{array}$ & $\begin{array}{l}\text { Wastewater from } \\
\text { industrial plants and } \\
\text { wastewater delivered } \\
\text { to the plant by gully } \\
\text { emptiers }\end{array}$ & 30000 \\
\hline
\end{tabular}

Table 2. The filtered volumes of wastewater and water samples, mass of sludge samples in both WWTPs

\begin{tabular}{|c|c|c|c|c|c|c|c|c|}
\hline \multirow[b]{3}{*}{ Type of sample } & \multicolumn{4}{|c|}{ Silesian region } & \multicolumn{4}{|c|}{ Warmia and Mazury region } \\
\hline & \multicolumn{2}{|c|}{ June } & \multicolumn{2}{|c|}{ November } & \multicolumn{2}{|r|}{ June } & \multicolumn{2}{|c|}{ November } \\
\hline & Symbol & $\begin{array}{c}\text { Filtered } \\
\text { volume per } \\
\text { sample } \\
\text { mass [ml/g] }\end{array}$ & Symbol & $\begin{array}{c}\text { Filtered } \\
\text { volume per } \\
\text { sample mass } \\
{[\mathrm{ml} / \mathrm{g}]} \\
\end{array}$ & Symbol & \begin{tabular}{|c|} 
Filtered \\
volume \\
per sample \\
mass [ml/g] \\
\end{tabular} & Symbol & $\begin{array}{c}\text { Filtered } \\
\text { volume per } \\
\text { sample mass } \\
{[\mathrm{ml} / \mathrm{g}]} \\
\end{array}$ \\
\hline Untreated wastewater & TC1 & 10 & TL1 & 40 & OC1 & 40 & OL1 & 40 \\
\hline $\begin{array}{l}\text { Wastewater after initial } \\
\text { settling tank }\end{array}$ & TC2 & 30 & TL2 & 30 & OC2 & 40 & OL3 & 40 \\
\hline $\begin{array}{l}\text { Wastewater after the } \\
\text { secondary settling tank }\end{array}$ & TC3 & 200 & TL3 & 300 & - & - & - & - \\
\hline $\begin{array}{l}\text { Wastewater in the biological } \\
\text { chamber }\end{array}$ & - & - & - & - & OC3 & 40 & OL3 & 20 \\
\hline $\begin{array}{l}\text { Wastewater after the } \\
\text { selector and } \\
\text { C-TECH reactor }\end{array}$ & TC4 & 150 & TL4 & 300 & - & - & - & - \\
\hline $\begin{array}{l}\text { Wastewater after the } \\
\text { multifunctional reactor }\end{array}$ & - & - & - & - & OC4 & 40 & OL4 & 40 \\
\hline Treated wastewater & TC5 & 150 & TL5 & 300 & OC5 & 200 & OL5 & 200 \\
\hline $\begin{array}{l}\text { River water before discharge } \\
\text { of treated wastewater }\end{array}$ & TC6 & 150 & TL6 & 300 & OC6 & 200 & OL6 & 400 \\
\hline $\begin{array}{l}\text { River water after discharge } \\
\text { of purified wastewater }\end{array}$ & TC7 & 150 & TL7 & 300 & $\mathrm{OC7}$ & 200 & OL7 & 400 \\
\hline Leachate after drainage & TC8 & 10 & TL8 & 30 & - & - & - & - \\
\hline $\begin{array}{l}\text { Sludge after mechanical } \\
\text { concentration }\end{array}$ & TC9 & 0.25 & TL9 & 0.25 & - & - & - & - \\
\hline $\begin{array}{l}\text { Sludge after gravity } \\
\text { concentration }\end{array}$ & TC10 & 0.25 & TL10 & 0.25 & - & - & - & - \\
\hline $\begin{array}{l}\text { Sludge after an open } \\
\text { fermentation pool }\end{array}$ & - & - & - & & OC8 & 0.25 & OL8 & 0.25 \\
\hline Sludge for management & - & - & - & & OC9 & 0.25 & OL9 & 0.25 \\
\hline
\end{tabular}

sediment samples - with the DNeasy Power Soil Kit (Qiagen) according to the manufacturer's protocol. After isolation, the DNA eluent was used for gene detection.

\section{PCR identification and detection}

The presence of beta-lactamase genes, including bla ${ }_{\mathrm{TEM}}$, bla $a_{\mathrm{OXA}}$ and bla $a_{\mathrm{SHV}}$ in the analyzed material was determined by PCR. The primers and reaction conditions are presented in Table 3 . The PCR reaction was performed in a volume of $15 \mu \mathrm{l}$ containing $1 \mu \mathrm{l}$ of genomic DNA of each sample and MasterMix NZYTaq II.

After PCR amplification of beta-lactamase genes, $5 \mu \mathrm{l}$ of each amplified DNA fragment was separated by electrophoresis in 1\% agarose gel (Sig$\mathrm{ma})$ stained with ethidium bromide $(0.5 \mathrm{mg} / \mathrm{ml})$.

\section{RESULTS AND DISCUSSION}

The growing consumption of antibiotics in developed countries around the world contributes 
to the emergence of antibiotic-resistant bacteria. Antibiotics and their derivatives are accumulated in the environment, including water bodies, sediments, groundwater and potable water. The proliferation of antibiotic-resistant bacteria and the accumulation of drugs in the environment are closely related to the high content of bacteria and antibiotics in raw municipal and hospital sewage which are not completely eliminated during treatment in WWTPs. Beta-lactam drugs are commonly used to combat bacterial diseases around the world. However, they are eliminated in the wastewater treatment processes and are relatively rarely detected in the environment. The municipal and hospital wastewater is particularly abundant in cephalosporins, and it is the main source of antibiotics in the treated sewage [Korzeniewska and Harnisz 2013; Kümmerer 2009]. The presence and spread of antibiotic resistance genes in wastewater have been confirmed by numerous studies [Amador et al. 2015; Korzeniewska et al. 2013; Zarfel et al. 2013; Mesa et al. 2006; Wen et al. 2016; Ojer-Usoz et al. 2014]. The greatest health risk is posed by the beta-lactamase genes which are very common and usually associated with bacteria of the family Enterobacteriaceae.

In the present study, the presence of bla${ }_{\mathrm{TEM}}, b l a_{\mathrm{OXA}}$ and $b l a_{\mathrm{SHV}}$ genes was examined in all wastewater samples collected from the mechanical and biological stages of treatment in the WWTP in the Warmia and Mazury Region and from the mechanical and biological stages of treatment accompanied by chemical precipitation of phosphorus in the WWTP in Silesia. The bla ${ }_{\text {TEM }}$ gene was detected in all wastewater samples collected from both WWTPs in June and November. It was identified in the treated wastewater and in the sludge that is deposited in the final stages of purification and is often used in industry and agriculture. The bla $a_{\mathrm{OXA}}$ gene was detected in the wastewater samples collected after each stage of treatment in the WWTP in Silesia in both June and November. However, this gene was not identified in river water downstream from the WWTP in Warmia and Mazury. In the samples collected in June, bla ${ }_{\text {OXA }}$ was not detected in sludge, but it was present in the samples collected in November. The bla $a_{\mathrm{SHV}}$ gene was not identified in any of the samples collected in June in Silesia. In November, the bla ${ }_{\mathrm{SHV}}$ gene was detected in downstream river water, but it was effectively eliminated in the WWTP and was not detected in the treated wastewater. In the WWTP in Warmia and Mazury, the bla $a_{\mathrm{SHV}}$ gene occurred in the wastewater samples collected in almost every stage of treatment in both June and November. These variations could be attributed to the different wastewater treatment methods in the analyzed WWTPs. In the industrialized region of Silesia, wastewater is additionally treated by chemical precipitation of phosphorus, which can promote gene elimination. The wastewater processed by the examined WWTPs can also differ in origin and composition. The presence of

Table 3. Primers and thermal conditions for PCR reactions

\begin{tabular}{|c|c|c|c|c|}
\hline Target & Primer sequences & PCR conditions & Size (bp) & References \\
\hline bla $_{\text {TEM }}$ & $\begin{array}{l}\text { AGTGCTGCCATAACCATGAGTG } \\
\text { CTGACTCCCCGTCGTGTAGATA }\end{array}$ & \multirow{3}{*}{$\begin{array}{c}5 \mathrm{~min} \text { at } 94^{\circ} \mathrm{C}, 1 \mathrm{~min} \text { at } 94^{\circ} \mathrm{C}, 1 \mathrm{~min} \text { at } \\
61^{\circ} \mathrm{C}, 1 \mathrm{~min} \text { at } 72^{\circ} \mathrm{C} \text { in } 30 \mathrm{cycles}, 5 \mathrm{~min} \\
\text { at } 72^{\circ} \mathrm{C}\end{array}$} & 431 & \multirow{3}{*}{$\begin{array}{l}\text { Kim et al. } \\
\text { [2009] }\end{array}$} \\
\hline bla $_{\text {oxA }}$ & $\begin{array}{c}\text { ATTATCTACAGCAGCGCCAGTG } \\
\text { TGCATCCACGTCTTTGGTG }\end{array}$ & & 296 & \\
\hline $\mathrm{bla}_{\mathrm{SHV}}$ & $\begin{array}{l}\text { GATGAACGCTTTCCCATGATG } \\
\text { CGCTGTTATCGCTCATGGTAA }\end{array}$ & & 214 & \\
\hline
\end{tabular}

Table 4. The results of PCR analysis in WWTP in Warmia and Mazury region

\begin{tabular}{|c|c|c|c|c|c|c|c|}
\hline \multicolumn{4}{|c|}{ June } & \multicolumn{4}{|c|}{ November } \\
\hline Type of sample & bla $_{\text {TEM }}$ & bla $_{\mathrm{OXA}}$ & bla $_{\mathrm{SHV}}$ & Type of sample & bla $_{\text {TEM }}$ & bla $_{\text {OXA }}$ & bla $_{\mathrm{SHV}}$ \\
\hline OC1 & + & + & + & OL1 & + & + & + \\
\hline $\mathrm{OC} 2$ & + & + & + & OL2 & + & + & + \\
\hline OC3 & + & + & + & OL3 & + & + & + \\
\hline $\mathrm{OC} 4$ & + & + & + & OL4 & + & + & + \\
\hline OC5 & + & + & + & OL5 & + & + & + \\
\hline OC6 & + & - & + & OL6 & + & - & + \\
\hline OC7 & + & + & - & OL7 & + & + & + \\
\hline OC8 & + & + & + & OL8 & + & + & - \\
\hline OC9 & + & - & + & OL9 & + & + & + \\
\hline
\end{tabular}


Table 5. The results of PCR analysis in WWTP in Silesian region

\begin{tabular}{|c|c|c|c|c|c|c|c|}
\hline \multicolumn{9}{|c|}{ June } & \multicolumn{5}{c|}{ November } \\
\hline Type of sample & $b / a_{\text {TEM }}$ & $b / a_{\text {OXA }}$ & $b / a_{\text {SHV }}$ & Type of sample & $b / a_{\text {TEM }}$ & $b_{\text {OXA }}$ & $b / a_{\text {SHV }}$ \\
\hline TC1 & + & + & - & TL1 & + & + & + \\
\hline TC2 & + & + & - & TL2 & + & + & + \\
\hline TC3 & + & + & - & TL3 & + & + & + \\
\hline TC4 & + & + & - & TL4 & + & + & + \\
\hline TC5 & + & + & - & TL5 & + & + & - \\
\hline TC6 & + & + & - & TL6 & + & + & + \\
\hline TC7 & + & + & - & TL7 & + & + & - \\
\hline TC8 & + & + & - & TL8 & + & + & - \\
\hline TC9 & + & + & - & TL9 & + & + & - \\
\hline TC10 & + & + & - & TL10 & + & + & - \\
\hline
\end{tabular}

antibiotic-resistance genes in the municipal and hospital wastewater treated in the WWTP in Silesia could also be attributed to higher morbidity and antibiotic consumption in autumn.

Osińska et al. [2017] detected bla $a_{\text {TEM }}$ and blaoxA genes in the samples from all analyzed stages of wastewater treatment: in river water sampled downstream from the WWTP, in raw and treated sewage, and in river water sampled upstream from the WWTP. The $b l a_{\text {SHV }}$ gene was identified in raw and treated sewage. The $b l a_{\text {TEM }}$ gene was also detected by Korzeniewska and Harnisz [2013a] in river water sampled downstream and upstream from the WWTP and in the samples collected from the bioreactor. The $b l a_{\mathrm{TEM}}$ gene was detected in 11 (26.8\%) out of the 90 ESBL-positive isolates of the family Enterobacteriaceae. In a study examining 43 ESBL isolates, Korzeniewska et al. [2013] identified the $b l a_{\mathrm{SHV}}$ gene in 17 isolates $(23.9 \%)$ and the $b l a_{\text {TEM }}$ gene in 14 isolates (19.7\%). These beta-lactamase genes are most commonly found in the bacteria of the Enterobacteriaceae family. In a study by Diallo et al. [2013], six out of the seven analyzed Escherichia coli isolates from municipal water carried the $b l a_{\text {TEM }}$ gene. All ESBL strains were resistant to imipenem. The authors also detected bla genes in the bacterial strains from slaughterhouse wastewater and treated wastewater. A study of 21 Spanish WWTPs revealed high levels of the $b l a_{\text {TEM }}$ gene $(47 \%)$ and lower levels of $b l a_{\mathrm{SHV}}$ $(17.4 \%)$ and $b l a_{\text {OXA }}(8.3 \%)$ genes in wastewater [Ojer-Usoz et al. 2014]. In a study examining 51 strains of beta-lactamase-producing bacteria of the Enterobacteriaceae family in the wastewater samples collected from WWTPs, 51.9\% strains were ESBL-positive. In addition, $35.2 \%$ of the strains harbored both ESBL and AmpC genes. The $b l a_{\mathrm{OXA}}$ gene was the predominant ESBL gene, and it was identified in $33.3 \%$ of the examined strains. Another prevalent gene was blaTEM which was present in $24.1 \%$ of the analyzed strains [Amador et al. 2015]. These findings indicate that both raw and treated wastewater is a rich source of genes encoding extended-spectrum beta-lactamases. These genes are not eliminated even in the WWTPs that deploy numerous wastewater processes and treatment stages.

Beta-lactam resistance genes were also detected in the untreated hospital wastewater, and the $b l a_{\text {TEM }}$ gene was found in $82 \%$ of all ESBL producers [Chagas et al. 2011]. In this study, the frequency of bla $a_{\mathrm{SHV}}$ and $b l a_{\mathrm{CTX}-\mathrm{M}}$ genes in the tested ESBL strains was determined at $48 \%$ and $67 \%$, respectively. These results indicate that hospital wastewater is highly contaminated with beta-lactam resistance genes. These studies also revealed that wastewater samples often simultaneously harbor $b l a_{\text {TЕM }}$ and $b l a_{\text {СTX-M }}$ genes. Interesting results were also reported by Dzierżanowska et al. [2010] who analyzed 110 isolates of Klebsiella pneumoniae from clinical facilities. Fortysix isolates harbored a single gene from the bla group, whereas as many as 64 isolates contained at least two bla genes. In these strains, $b l a_{\mathrm{TEM}}$ and $b l a_{\text {SHV }}$ genes were dominant. In other studies of $K$. pneumianoae, the genetic determinants of bla${ }_{\mathrm{TEM}}$ and $b l a_{\mathrm{SHV}}$ were detected in $100 \%$ and $50 \%$ of isolates, respectively. In Escherichia coli strains, the bla $_{\text {TEM }}$ gene occurred in 92 cases (89\%). It is also worth noting that all $K$. pneumoniae and $E$. coli strains additionally carried the bla $a_{\text {СТХ-м }}$ gene, which points the presence of correlations between these genes [Mugnaioli et al. 2006]. Similar results were reported by Sana et al. [2011] in a clinical study of Escherichia coli, where $45.2 \%$ of 73 ESBL-positive isolates harbored the $b l a_{\text {OXA }}$ gene. The $b l a_{\mathrm{SHV}}$ gene was somewhat less prevalent. 
These findings demonstrate that the clinical facilities with an abundance of resistant strains and very high consumption of antibiotics significantly influence the prevalence of antibiotic resistance genes in wastewater and the environment.

\section{CONCLUSIONS}

In the current study, the antibiotic resistance genes were detected in the final stages of wastewater treatment; therefore, the effectiveness of the evaluated wastewater treatment methods in eliminating resistance genes could not be reliably ascertained. These findings suggest that the mechanical and biological methods of wastewater treatment in WWTPs do not completely remove the antibiotic resistance genes from sewage. The correlations between the sampling season and the presence of antibiotic resistance genes in wastewater could not be determined because highly similar results were noted for all examined genes. Wastewater is a specific hotspot of the resistance genes and antibiotic-resistant bacteria. Beta-lactamase genes are discharged with treated effluents into the environment. They can spread over long distances, increase the antibiotic resistance gene pool and contribute to antimicrobial resistance worldwide. The bacterial resistance to antibiotics is a growing clinical problem and a public health threat. Environmental monitoring and new methods for eliminating genetic determinants of drug resistance are required to effectively address these problems.

\section{Acknowledgements}

Wiktor Zieliński is a recipient of a scholarship from the Programme Interdisciplinary Doctoral Studies in Bioeconomy (POWR.03.02.0000-I034/16-00), which is funded by the European Social Funds.

This study was supported by grants from the National Science Center (Poland): No. 2017/27/B/ NZ9/00267 and No. 2017/26/M/NZ9/0007

\section{REFERENCES}

1. Amador P.P., Fernandes R.M., Prudencio M.C., Barreto M.P., Duarte I.M. 2015. Antibiotic resistance in wastewater: Occurrence and fate of Enterobacteriaceae producers of Class A and Class C $\beta$-lactamases, Journal of Environmental Science and Health, Part A, 50, 26-39.
2. Chagas T.P., Seki L.M., Cury J.C., Oliveira J.A., Davila A.M., Silva D.M., Asensi M.D. 2011. Multiresistance, beta-lactamase-encoding genes and bacterial diversity in hospital wastewater in Rio de Janeiro, Brazil, Journal of Applied Microbiology, 111, 572-581.

3. Diallo A.A., Brugere H., Kerouredan M., Dupouy V., Toutain P.L., Bousquet-Melou A., Oswald E., Bibbal D. 2013. Persistence and prevalence of pathogenic and extended-spectrum beta-lactamaseproducing Escherichia coli in municipal wastewater treatment plant receiving slaughterhouse wastewater, Water Research, 47(13), 4719-4729.

4. Dzierżanowska D., Kamińska W., Semczuk K., Borowiec D., Matysiak M., Szumała-Kąkol A., Gierczyński R., Patzer J.A. 2010. Carriage of genes for various extended-spectrum $\beta$-lactamases: a novel resistance strategy of Klebsiella pneumoniae in Poland, International Journal of Antimicrobial Agents, 35, 392-395.

5. ECDC, 2017. European Centre for Disease Prevention and Control, SURVEILLANCE REPORT: Antimicrobial consumption, Annual Epidemiological Report for 2017, https://www.ecdc.europa.eu/sites/ portal/files/documents/AER_for_2017-antimicrobial-consumption.pdf

6. Harnisz M., Korzeniewska E. 2018. The prevalence of multidrug-resistant Aeromonas spp. In the municipal wastewater system and their dissemination in the environment, Science of Total Environment, 626, 377-383.

7. Huang J.J., Hu H.Y., Lu S.Q., Li Y., Tang F., Lu Y., Wei B. 2012. Monitoring and evaluation of antibiotic-resistant bacteria at a municipal wastewater treatment plant in China, Environ. Int., 42, 31-36.

8. Kelly B.G., Vespermann A., Bolton D.J. 2009. Gene transfer events and their occurrence in selected environments, Food Chem. Toxicol., 47, 978-983.

9. Kim J., Jeon S., Rhie H., Lee B., Park M., Lee H., Lee J., Kim S. 2009. Rapid Detection of Extended Spectrum $\beta$-Lactamase (ESBL) for Enterobacteriaceae by use of a Multiplex PCR-based Method, Infection and Chemotherapy, 41(3), 181-184.

10. Korzeniewska E., Harnisz M. 2013. Beta-lactamase-producing Enterobacteriaceae in hospital effluents, Journal of Environmental Management, $123,1-7$.

11. Korzeniewska E., Harnisz M. 2013a. Extendedspectrum beta-lactamase (ESBL)-positive Enterobacteriaceae in municipal sewage and their emission to the environment, Journal of Environmental Management, 128, 904-911.

12. Korzeniewska E., Harnisz M. 2018. Relationship between modification of activated sludge wastewater treatment and changes in antibiotic resistance 
of bacteria, Science of the Total Environment, 639, 304-315.

13. Korzeniewska E., Korzeniewska A., Harnisz M. 2013. Antibiotic resistant Escherichia coli in hospital and municipal sewage and their emission to the environment, Ecotox. Environ. Safe., 91, 96-102.

14. Kummerer K. 2009. Antibiotics in the aquatic environment--a review--part I, Chemosphere, 75(4), 417-434.

15. Li D., Yang M., Hu J., Zhang J., Liu R., Gu X., Zhang Y., Wang Z. 2009. Antibiotic-resistance profile in environmental bacteria isolated from penicillin production wastewater treatment plant and the receiving river, Environ. Microbiol., 11, 1506-1517.

16. Marti E, Huerta B., Rodriguez-Mozaz S., Barcelo' D., Jofre J., Balcazar J.L., 2014. Characterization of ciprofloxacin-resistant isolates from a wastewater treatment plant and its receiving river, Water Research, 61, 67-76.

17. Mesa R.J., Blanc V., Blanch A.R., Cortes P., Gonzalez J.J., Lavilla S., Miro E., Muniesa M., Saco M., Tortola M.T., Mirelis B., Coll P., Llagostera M., Prats G., Navarro F. 2006. Extended-spectrum b-lactamase-producing Enterobacteriaceae in different environments (humans, food, animal farms and sewage), Journal of Antimicrobial Chemotherapy, 58, 211-215.

18. Moura A., Pereira C., Henriques I., Correia A. 2012. Novel gene cassettes and integrons in antibiotic-resistant bacteria isolated from urban wastewaters, Res. Microbiol., 163 (2), 92-100.

19. Mugnaioli C., Luzzaro F., De Luca F., Brigante G., Perilli M., Amicosante G., Stefani S., Toniolo A., Rossolini G.M. 2006. CTX-M-Type ExtendedSpectrum $\beta$-Lactamases in Italy: Molecular Epidemiology of an Emerging Countrywide Problem, Antimicrobial Agents and Chemotherapy, 50(8), 2700-2706.

20. Ojer-Usoz E., Gonzalez D., Garcia-Jalon I., Vitas I. 2014. High dissemination of extended-spectrum b-lactamase-producing Enterobacteriaceae in effluents from wastewater treatment plants, Water Research, 56, 37-47.

21. Osińska A., Korzeniewska E., Harnisz M., Niestępski S. 2017. The prevalence and characterization of antibiotic-resistant and virulent Esch- erichia coli strains in the municipal wastewater system and their environmental fate, Science of the Total Environment, 577, 367-375.

22. Paterson D.L., Bonomo R.A. 2005. ExtendedSpectrum Beta-Lactamases: a Clinical Update, Clinical Microbiology Reviews, 18, 657-686.

23. Reinthaler F.F., Feierl G., Galler H., Haas D., Leitner E., Mascher F., Melkes A., Posch J., Winter I., Zarfel G., Marth E. 2010. ESBL-producing E. coli in Austrian sewage sludge, Water Research, 44, 1981-1985.

24. Rizzo L., Manaia C., Merlin C., Schwartz T., Dagot C., Ploy M.C., Michael I., Fatta- Kassinos D. 2013. Urban wastewater treatment plants as hotspots for antibiotic resistant bacteria and genes spread into the environment: a review, Sci. Total Environ., 447, 345-360.

25. Sana T., Rami K., Racha B., Fouad D., Marcel A., Hassan M., Sani H., Monzer H. 2011. Detection of genes TEM, OXA, SHV and CTX-M in 73 clinical isolates of Escherichia coli producers of extended spectrum Beta-lactamases and determination of their susceptibility to antibiotics, The Interenational Arabic Journal of Antimicrobial Agents, 1(1), 1-6.

26. Wen Q., Yang L., Duan R., Chen Z. 2016. Monitoring and evaluation of antibiotic resistance genes in four municipal wastewater treatment plants in Harbin, Northeast China, Environmental Pollution, 212, 34-40.

27. West B.M., Liggit P., Clemans D.L., Francoeur S.N. 2010. Antibiotic resistance, gene transfer, and water quality patterns observed in waterways near CAFO farms and wastewater treatment facilities, Water Air Soil Pollut., 217, 473-489.

28. Xu J., Xu Y., Wang H., Guo C., Qiu H., He Y., Zhang Y., Li X., Meng W. 2015. Occurrence of antibiotics and antibiotic resistance genes in a sewage treatment plant and its effluent-receiving river, Chemosphere, 119, 1379-1385.

29. Zarfel G., Galler H., Feierl G., Haas D., Kittinger C., Leitner E., Grisold A.J., Mascher F., Posch J., Pertschy B., Marth E., Reinthaler F.F. 2013. Comparison of extended spectrum-b-lactamase (ESBL) carrying Escherichia coli from sewage sludge and human urinary tract infection, Environmental Pollution, 173, 192-199. 